\title{
DEFORMATIONAL STRUCTURES IN THE FIRST SALPAUSSELKÄ END MORAINE, JOUTSENONKANGAS, SOUTH-EASTERN FINLAND
}

\author{
MATTI SAARNISTO
}

\begin{abstract}
SAARNISTO, MATTI 1977: Deformational structures in the First Salpausselkä end moraine, Joutsenonkangas, south-eastern Finland. Bull. Geol. Soc. Finland 49: 65-72.

Deformational structures in glaciofluvial deltaic sand of the First Salpausselkä end moraine have been described and their origin interpreted on the basis of the palaeogeographical setting of the site. The structures, including a »load wedge», formed quickly after the accumulation of the sediment as a result of vertical loading pressure. It is perhaps reasonable to expect such structures in a variety of depositional environments.
\end{abstract}

Matti Saarnisto, Department of Geology, University of Oulu, SF-90100 Oulu 10, Finland.

\section{Description of the deformational structures}

This note describes and interpretes an unusual wedge-like structure, associated with other deformational features, in glaciofluvial sediments which form part of the First Salpausselkä (Ss I) end moraine. The gravel pit, where the structures were observed in summer 1975, is situated in an extensive outwash delta, about $0.5 \mathrm{~km}$ west of the Lappeenranta-Joutseno border, immediately to the south of Highway 6. (Fig. 1; topographic map 313410 , coordinates $x=677760, y=57600$ ).

The gravel pit exposes the common stratigraphy of the Ss I: a bed several metres thick of coarse glaciofluvial sediment overlying fine material. Fig. 2 shows the general strati- graphy of the site. The boundary between coarse and finer material is sharp and in places the uppermost part of the finer sediment shows signs of erosion (Fig. 3).

Both beds display deformational features. In the upper part of the pit, Aartolahti (1970, site 2, Figures 3 and 10) has described several well formed fossil ice wedges in coarse glaciofluvial gravel (bed C). These belong to the tundra polygons found on the ground surface (see below). Similarly, fossil ice wedges in the Ss I have been described by Donner, Lappalainen, and West (1968). The deformational structures considered here, however, are to be found in the lower bed of the finer glaciofluvial material, in the south-western corner of the pit. The bed consists of two dis- 

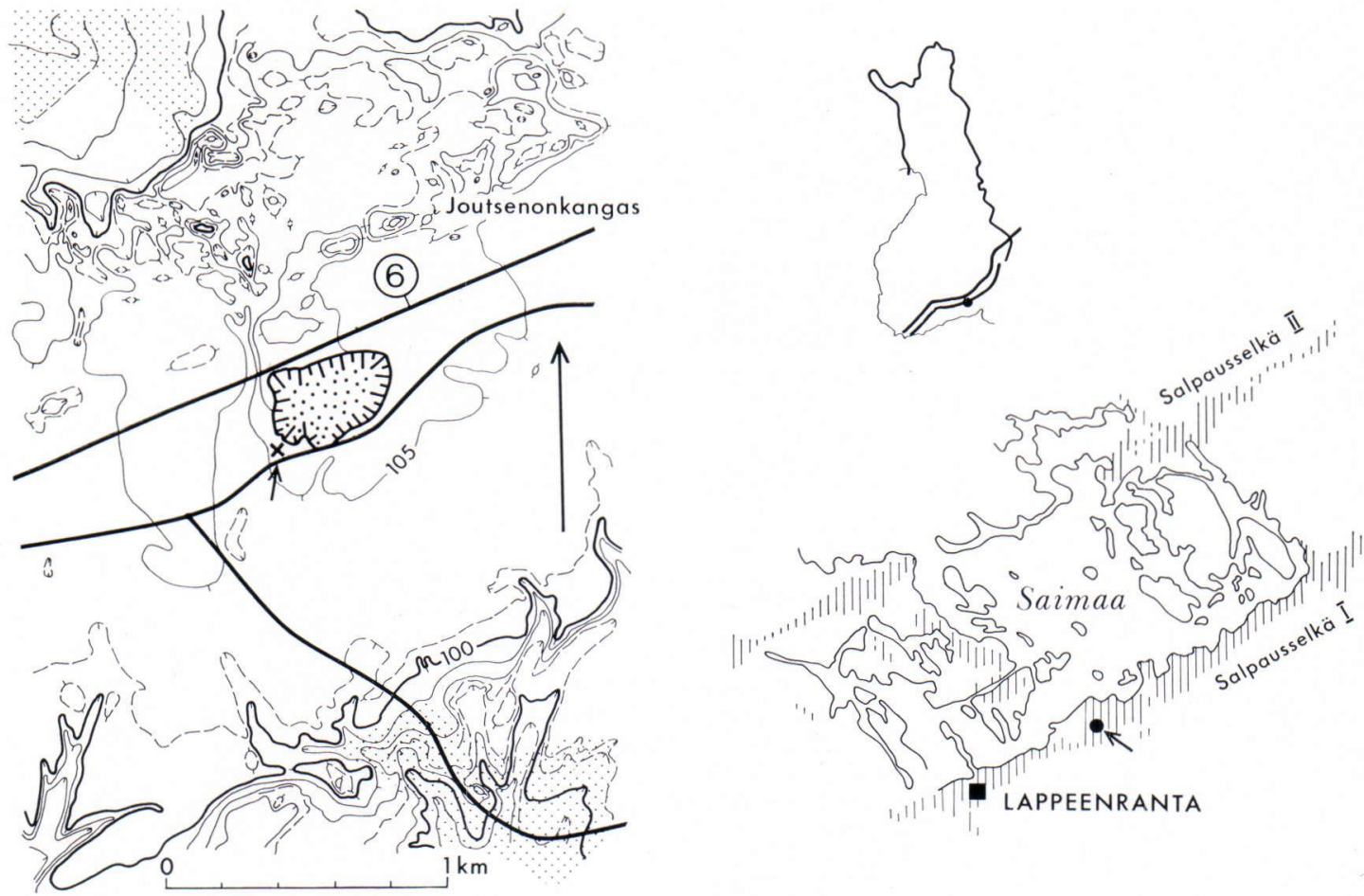

Fig. 1. Map showing the Salpausselkä end moraineses and the Joutsenonkangas pit to the south of Lake Saimaa.

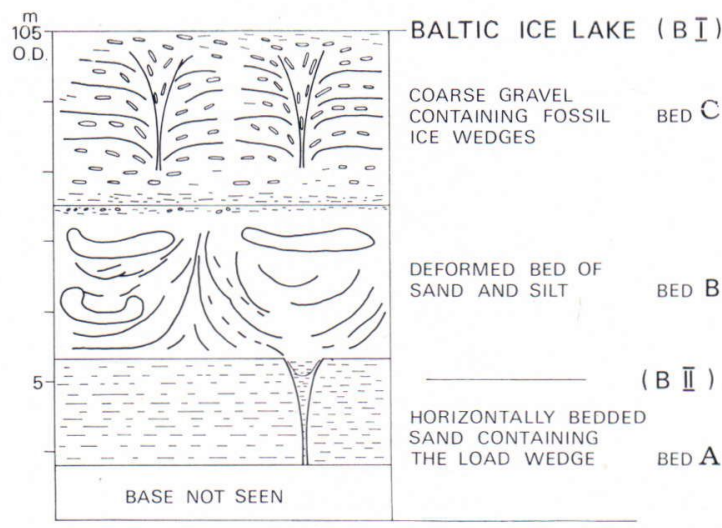

Fig. 2. A sketch of the general stratigraphy at the site of the deformational structures. A bed of coarse glaciofluvial material with fossil ice wedges (C) overlies a thoroughly contorted bed of fine glaciofluvial material, sand and silt (B) resting on an undisturbed layer of horizontally bedded sand (A). The peculiar wedge-shaped structure penetrates vertically downwards into this unit. The levels of the B I and B II stages of the Baltic Ice Lake are also indicated. tinctly different units. The upper about $2 \mathrm{~m}$ thick horizon (bed B) is thoroughly contorted. It rests on an undisturbed layer of horizontally bedded sand (bed A), which extends to the bottom of the pit (Figures 2 and 3). From the top of this layer at least one wedge-shaped structure penetrates the sediment verically. The form closely resembles that of a fossil ice wedge, but other structural features and the material seem to suggest a different origin.

The wedge is approximately $1.5 \mathrm{~m}$ deep and $0.4 \mathrm{~m}$ wide $\mathrm{a}$ t the top (Figures 4,5 and 6 ). The sides of the wedge grade upward into the overlying contorted bed without unconformity, and they are steep in the upper part $\left(80^{\circ}\right)$. They become more gently sloping, however, at a depth of about $0.5 \mathrm{~m}$. The lower 


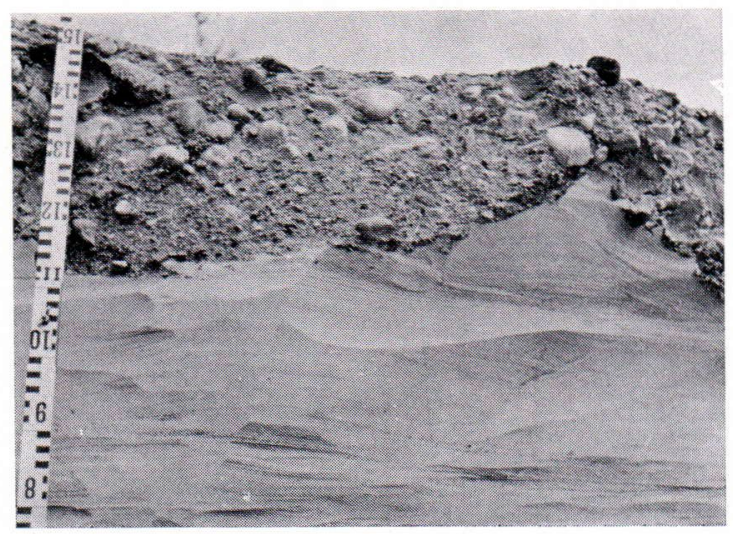

Fig. 3. Photograph of the sharply eroded boundary between the coarse gravel and sand beds in the eastern section of the pit. The current direction was towards the right.

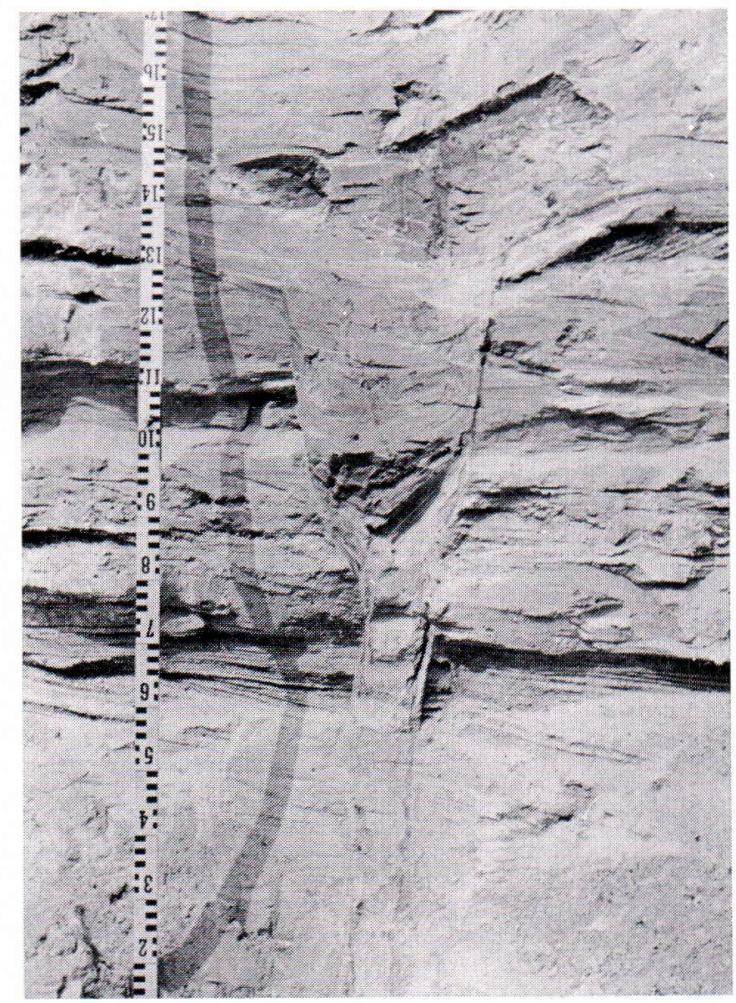

Fig. 4. The wedge shaped formation called here a "load wedge» in horizontally bedded fine sand (bed A). The walls of the wedge grade upwards into the overlying controrted bed without unconformity. Further details in the text.

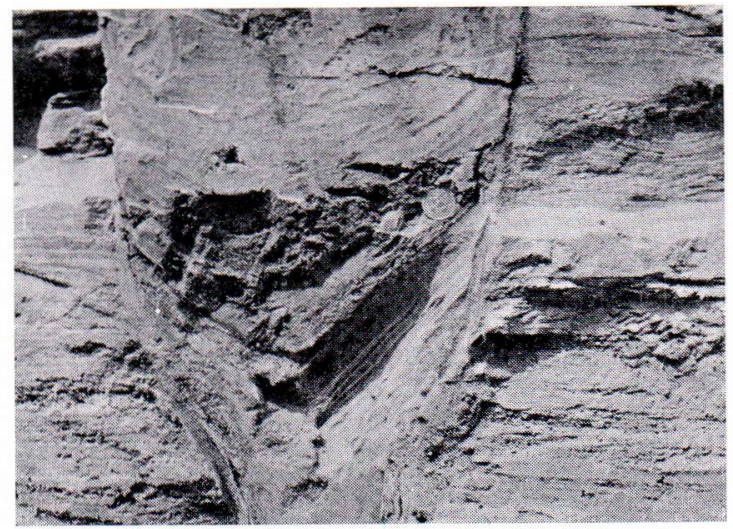

Fig. 5. A close up of the »load wedge» showing the individual layers within the wedge and the undisturbed layers bordering the wedge. The diameter of the coin is $25 \mathrm{~mm}$.

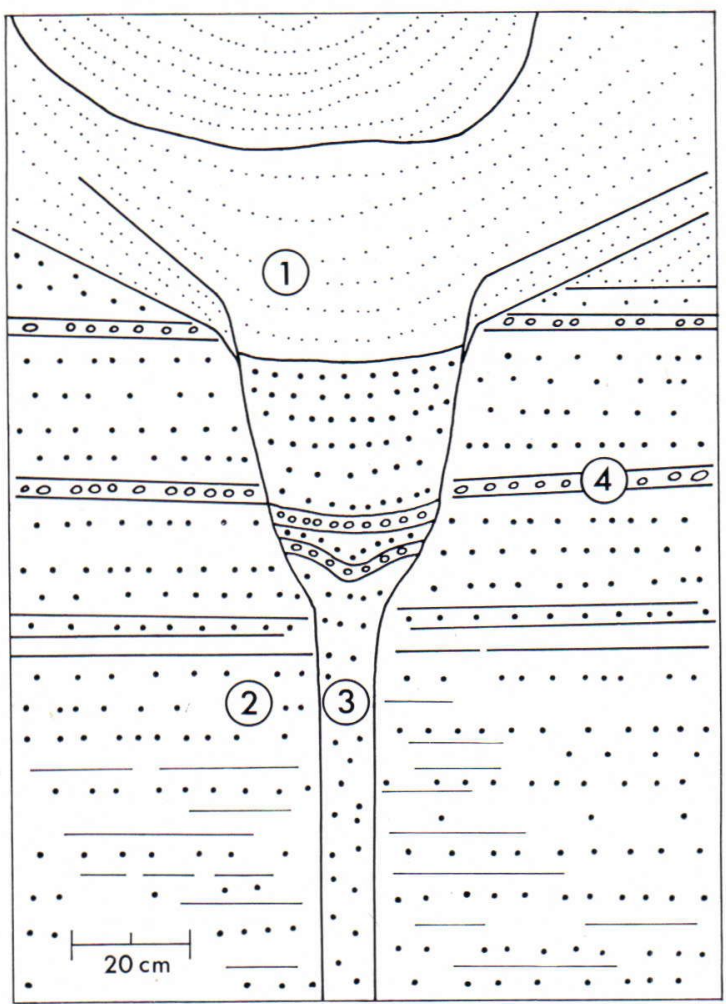

Fig. 6. A sketch of the "load wedge» showing dimensions and structural features. The numbers refer to grain size analyses shown in Fig. 7 . 
part of the wedge consists of a $10 \mathrm{~cm}$ broad vertical tail.

The wedge-fill consists of somewhat collapsed fine sand and silt in which the original bedding is preserved. The layers are inclined toward the middle of the wedge and are up to $20 \mathrm{~cm}$ lower than the corresponding horizontal strata bordering the wedge. The adjacent layers end abruptly without any bending close to the wedge. The narrow lower end of the wedge is filled with unstratified fine sand. Material in the wide upper part originates from the deformed bed above. The boundary between it and the original sediment is emphasized by iron staining, which also covers the walls of the wedge. The upper sediment is also finer and better sorted than the lower material which is present in the wedge and the surrounding layers.

Thus the wedge seems to be closely connected with the contorted bed (B) above. The deformations are confined to this nearly horizontal bed which is about $2 \mathrm{~m}$ thick and exposed for about $50 \mathrm{~m}$. The contortions are not present either in the overlying or underlying beds. The deformed structures include rounded sack-like sand bodies between which project pointed tongues of finer material. In places, these structures are completely contorted, but generally the sack-like bodies are of the same general size and character. The structures are best developed in the lower and middle part of the bed, where the sand bodies are up to $1 \mathrm{~m}$ in width and $0.5 \mathrm{~m}$ in depth (Fig. 8). In the upper part of the bed the structures are more elongated.

The material in the sand bodies is stratified. The stratification is parallel to the boundaries of the structures. The margins of the structures are curved inward. The material consists of sand, whereas the material in the tongues is finer, very well sorted coarse silt (see below). The structure indicates that the sand has been depressed into the finer sediment.

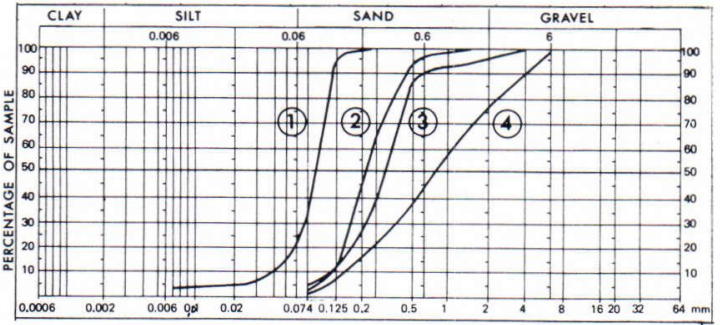

Fig. 7. Grain size analyses of material from the deformational features and related layers. The location of the samples is shown by the numbers in Fig. 6.

\section{Interpretation}

The above structures resemble the »balland-pillow» formations described by Potter and Pettijohn (1963, pp. 148-152) or large scale »load casts» and closely related »flame structures». The internal structure of the sand bodies suggests a ball-and-pillow type origin. They indicate vertical movement in a hydroplastic bed. A ball-and-pillow structure would also suggest a single sudden formation, after the accumulation of the sand layer. The wedge-shaped structure below also suggests an abrupt single phase of formation. This is shown by the undisturbed sides and the collapsed, but otherwise undisturbed internal structure. Other mechanisms which might initiate deformation resembling those described above are overloading of watersaturated sediment or frost action. The latter produces involutions (e.g. Potter and Pettijohn 1963, pp. 145-148, Washburn 1973, pp. 147-149).

In order to put these deformational structures in context their palaeogeographical setting should be borne in mind. This includes:

1. the deposition of the delta plain,

2. its emergence from the Baltic waters,

3 . the contemporaneous climatic conditions.

1. As mentioned previously, the general stratigraphy of coarse material overlying fine 


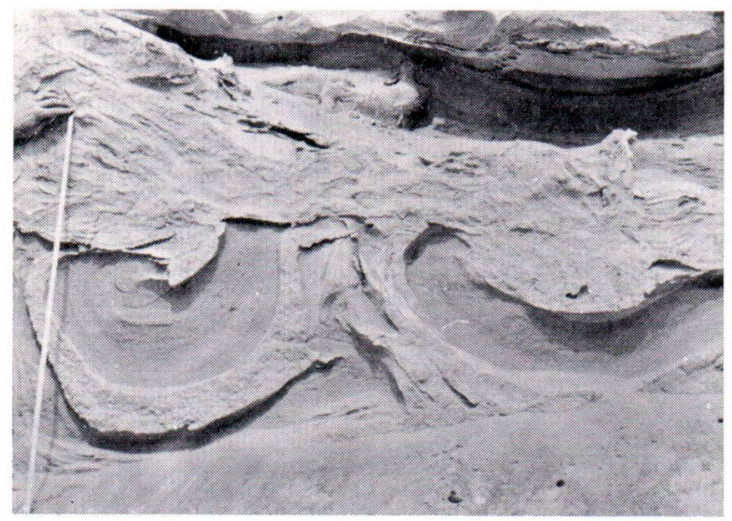

Fig. 8. »Ball-and-pillow» and »flame» structures in the contorted bed (B). The bedding is parallel to the boundaries of the pillows. The length of the stick is one metre.

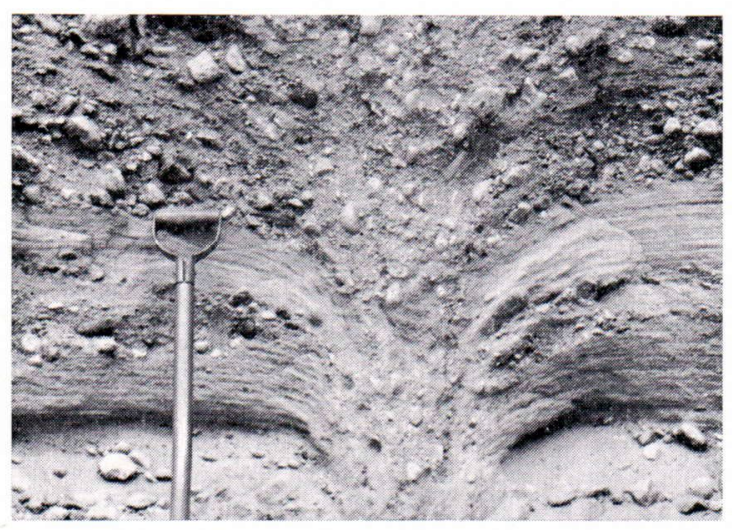

Fig. 9. A fossil ice wedge in coarse gravel (bed C) at Joutsenonkangas. Typical features are: a wedge-like shape; infilling material differing from the material bordering the walls of the wedge; stones and pebbles standing vertical in the wedge; the layers bordering the wedge dipping downwards; and, in addition, a contorted layer about $0.5 \mathrm{~m}$ thick on top of the wedge representing the active layer (see e.g. Svensson 1959, pp. 15-16, Dylik and Maarleveld 1967, p. 15).

sediment observed in Joutsenonkangas is not only a local phenomenon, but has been described from many localities along the Salpausselkä I moraine. This suggests that the sequence may be attributed to an ice margin oscillation. In many places in the Salpausselkä, for example east of Lahti, till beds occur overlying fine glaciofluvial material, indicating readvances. The fine sediment would have been deposited when the ice margin was inside the Salpausselkä ridge. An aeolian origin for some of the water-laid sediments may be considered since similar aeolian silt covers supra-aquatic hills in the eastern foreland of the Salpausselkä (Mielonen 1965). The coarse material (bed C) was probably deposited when the ice margin stood at the proximal side of the end moraine at Joutsenonkangas, that is about $1 \mathrm{~km}$ north of the gravel pit (Fig. 1).

2. The surface of the plain is at $105 \mathrm{~m}$ and this corresponds to the highest level of the Baltic Ice Lake (B I, Sauramo 1958). The plain emerged from the Baltic when the water level first fell about $5 \mathrm{~m}$ to the B II level. In southern Lake Saimaa, B II forms the highest shoreline immediately inside the Salpausselkä I moraine indicating that the delta plain emerged soon after the ice margin started to retreat from Ss I (Saarnisto 1970, Appendices V and VI). The shoreline B III, corresponding to the highest delta plains of the Salpausselkä II moraine, is situated 10 metres below the B I level at Salpausselkä I.

3. The fossil ice wedges found in southern Finland occur in the Salpausselkä belt, and the formation of the wedges is placed at the time of formation of the Salpausselkäs, after their emergence from Baltic Ice Lake, in the cold Younger Dryas period or immediately after it (Donner et al. 1968; Aartolahti 1970). The fossil ice wedges in the upper part of the gravel pit in Joutsenonkangas are indicative of permafrost conditions after the emergence of the delta plain. Fig. 9 shows the typical features of a fossil ice wedge, which differ from those found in wedge-shaped structure described earlier. Independent pollen evidence also shows that true tundra conditions prevailed during the formation of the Salpausselkä moraines (Repo and Tynni 1969; Hyvärinen 1973). The Joutsenonkangas site was emergent during the Younger Dryas peri- 
od for 500 to 700 years depending on the choice between the somewhat differing ice retreat chronologies of Sauramo (1929) or Niemelä (1971). This gives some idea of the duration of permafrost conditions.

Thus the deformational structures could have been formed: (1) under water during the deposition of the coarse glaciofluvial bed, (2) as result of increasing weight after the emergence of the sediment from the Baltic Ice Lake or (3) during the formation of permafrost. As the upper part of the plain emerged from the Baltic Ice Lake, frost began to penetrate downward. In a closed system between the frozen ground above and the ground water level below, regulated by the Baltic, vertical pressure developed which might have given rise to the deformations. On the other hand, the structures indicate that the deformation formed in unfrozen water-saturated sediment. However, once the frost had penetrated down there was no alternating freezing and thawing required for involutions to form. The ice wedges in the uppermost bed are up to $3.5 \mathrm{~m}$ deep and extend almost into the deformed bed, and the active layer above them was only $0.5 \mathrm{~m}$ thick. Thus the ground immediately beneath the ice wedges must have been permanently frozen.

It is not clear whether the pressure caused by the downward penetrating ice was essential or whether the loading pressure of the overlying sediment itself was enough for the formation of the deformational structures. The examples of ball-and-pillow formations quoted by Potter and Pettijohn (1963, pp. 151 -152) do not require frost pressure. It seems clear, however, that the deformations formed as a result of vertical loading pressure. The internal stratification of the sack-like sand bodies indicates an instantaneous formation which is also evident from the wedge structure below. Here vertical pressure obviously has produced a fracture in the undisturbed horizontally bedded layer. The formation mechanism was therefore overloading.

Kuenen (1958) has produced ball-and-pillow structures experimentally by applying a shock to a deposit of interstratified sand and clay. He suggested that an earthquage shock might be the triggering mechanism to produce this structure. In the case of Joutsenonkangas, an earthquake shock cannot be entirely ruled out. Kujansuu (1964, pp. 30-36) has demonstrated bedrock faults in Lapland dating from the time of deglaciation. Rapid land uplift at that time caused faults to occur and related to these would be earthquakes. This explanation requires, however, more supporting evidence before it can be proberly considered as the cause of the deformational structures.

The wedge-shaped structure in bed A cannot be termed a "fossil ice wedge», because it has never been filled with ice. It is not a "ground wedge» or a "sand wedge». These originate as open fissures formed by frost cracking which then become infilled by sand (Péwé 1959, Dylik 1966, Goździk 1973). Butrym et al. (1964, p. 29) suggest the term »clastic wedge» for structures of dubious origin. However, the origin of the Joutsenonkangas wedge seems to be so obvious that the genetic term »load wedge» is suggested here.

\section{Discussion}

Deformational structures closely resembling the present features have been recognized by Repo and Tynni (1969, p. 223 and Fig. 19) in a glaciofluvial delta plain of Salpausselkä II at Kitee. They are situated in a fine grained bed underlying coarse glaciofluvial sediment. These authors assumed that the deformations were formed as a result of loading during the deposition of the upper bed. However, Aartolahti (1970) has described fossil ice wedges from sections in the same plain deposits and therefore frost pressure 
cannot be entirely discounted as a possible explanation.

Some of the deformational features in the Salpausselkä belt can be clearly attributed to glacio-tectonic structures formed by the movement pressure of glacial ice. In a large pit in Salpausselkä I at Lahti similar sack-like and flame structures have been observed in fine sand and silt underneath approximately $15 \mathrm{~m}$ of till.

Deformational structures in fine glaciofluvial sediment, which were formed contemporaneously with the sedimentation, have been described from Finland by M. Okko (1967) and Aario (1971). These resulted from differential pressure conditions and gravity-induced rearrangement within the sediments. Virkkala (1957) has described various deformational structures from glaciofluvial sediments in southern Finland and has interpreted them as periglacial involutions. More recently similar structures have been found from sites which were submerged during lateglacial time and therefore an alternative mechanism seems necessary to explain them (Virkkala, personal communication).

The deformational structures described in the present paper formed after the accumulation of the deformed bed, as a result of loading pressure. Thus the deformation of the stratified sediments is not typical of any particular environment. The later is often difficult to determine, without any supporting evidence, on the basis of very similar structures. Many deformational processes, such as load casting, can produce features similar to periglacial involutions as has been emphasized by several workers (e.g. Johnson 1959; Butrym et al. 1964; Washburn 1973). Fossil ice wedges casts on the other hand, have been considered among the few acceptable criteria for former permafrost (Washburn 1973 , p. 93). The »load wedge» at Joutsenonkangas indicates that all wedge shaped formations, as well as other deformational features, should be carefully examined before palaeoenvironmental reconstructions are attempted.

In Finland the geological setting of a deformed section can often be readily assertained. Deglaciation and land uplift history provide information of different sedimentary environments such as the possible time of deposition, the climate, the location of the ice margin, supra-aquatic or sub-aquatic accumulation, water depth and the time of emergence of the deposits. This may help in the classification of deformational structures. For the present the data available in Finland is not sufficient for such a classification.

Since deformational structures have been reported from a variety of depositional environments it is perhaps reasonable to expect such structures in both glaciofluvial and indeed fluvial deposits where coarse material rests on relatively finer material.

Acknowledgements - The author wants to thank Dr. P. Gibbard for invaluable discussions and for checking the English of the manuscript.

\section{References}

Aario, R. (1971) Syndepositional deformation in the Kurkiselkä esker, Kiiminki, Finland. Bull. Geol. Soc. Finland 43: 163-172.

Aartolahti, T. (1970) Fossil ice-wedges, tundra polygons and recent frost cracks in southern Finland. Ann. Acad. Sci. Fennicae, A. III, 107. $26 \mathrm{p}$.
Butrym, J., Cegla, J., Dzulyński, S. and Nakonieczny, S. (1964) New interpretation of "periglacial structures». Folia Quaternaria 17. 34 p. Kraków.

Donner, J., Lappalainen, V. and West, R. G. (1968) Ice wedges in south-eastern Finland. Geol. Fören. Stockh. Förh. 90: 112-116. 
Dylik, J. (1966) Problems of ice-wedge structures and frost-fissure polygons. Biul. Perygl. 15: $241-291$.

Dylik, J. and Maarleveld, G. C. (1967) Frost cracks, frost fissures and related polygons. Meded. geol. Sticht. Nieuwe Ser. 18: 7-21.

Goździk, J. (1973) Origin and stratigraphical position of periglacial structures in Middle Poland. (In Polish with an English summary). Acta Geogr. Lodziensia 31. 117 p.

Hyvärinen, H. (1973) The deglaciation history of eastern Fennoscandia - recent data from Finland. Boreas 2: 85-102.

Johnsson, G. (1959) True and false ice-wedges in southern Sweden. Geogr. Ann. 41: 15-33.

Johnsson, G. (1962) Periglacial phenomena in southern Sweden. Geogr. Ann. 44: 378-404.

Kuenen, Ph. H. (1958) Experiments in geology. Trans. Geol. Soc. Glasgow 23. 28 p.

Kujansuu, R. (1964) Nuorista siirroksista Lapissa. Summary: Recent faults in Lapland. Geologi 16: $30-36$.

Mielonen, M. (1965) Die Vaara-Siedlung in NorthKarelien und ihre Beziehung zur Landwirtschaft. Fennia 93. 171 p.

Niemelä, J. (1971) Die quartäre Stratigraphie von Tonablagerungen und der Rückzug des Inlandeises zwischen Helsinki und Hämeenlinna in Südfinnland. Geol. Surv. Finland Bull. 253. $79 \mathrm{p}$.

Okko, M. (1967) Convolute lamination in a Late Pleistocene deposit at Pannujärvi, Tuulos, Fin- land. Compt. Rend. Soc. Géol. Finlande 39: $123-131$.

Péwé, T. L. (1959) Sand-wedge polygons (tesselations) in the McMurdo Sound region, Antarctica. Am. J. Sci. 257: 545-552.

Péwé, T. L., Church, R. E. and Andresen, M. J. (1969) Origin and paleoclimatic significance of large-scale patterned ground in the Donnelly Dome Area, Alaska. Geol. Soc. Am. Spec. Paper 103. $87 \mathrm{p}$.

Potter, P. E. and Pettijohn, F. J. (1963) Paleocurrents and basin analysis. Springer-Verlag, Berlin-Göttingen-Heidelberg. $296 \mathrm{p}$.

Repo R. and Tynni, R. (1969) Morphologischstratigraphische Grundzüge des östlichen Salpausselkä — Gebiets. Bull. Geol. Soc. Finlande 41: $203-229$.

Saarnisto, M. (1970) The Late Weichselian and Flandrian History of the Saimaa Lake Complex. Soc. Sci. Fennica. Commentat. PhysicoMath. 37. 107 p.

Sauramo, M. (1929) The Quaternary geology of Finland. Bull. Comm. Géol. Finlande 86. 110 p.

Sauramo, M. (1958) Die Geschichte der Ostsee. Ann. Acad. Sci. Fennicae, A. III, 51. 522 p.

Virkkala, K. (1959) On the Lateglacial frost phenomena in southern Finland. Bull. Comm. Géol. Finlande 184: 21-40.

Washburn, A. L. (1973) Periglacial processes and environments. Edward Arnold, London. 320 p.

Manuscript received, November 29, 1976. 